\title{
Prediction of Flower Emergence and Evaluation of Cropping Potential in Selected Banana Cultivars (Musa sp.) Cultivated in Subtropical Conditions of Coastal Alabama
}

\author{
Edgar L. Vinson, III, Elina D. Coneva ${ }^{1}$, Joseph M. Kemble, \\ Floyd M. Woods, and Jeff L. Sibley \\ Department of Horticulture, Auburn University, 101 Funchess Hall, Auburn \\ University, AL 36849
}

Esendugue G. Fonsah

Department of Agricultural and Applied Economics, University of Georgia, Tifton Campus, 2360 Rainwater Road, Tifton, GA 31793

Penelope M. Perkins-Veazie

Department of Horticulture, North Carolina State University, 600 Laureate Way, Suite 1329, Kanapolis, NC 28081

\section{J. Raymond Kessler \\ Department of Horticulture, Auburn University, 101 Funchess Hall, Auburn University, AL 36849}

Additional index words. Musa, subtropical, banana production, cold-tolerant, non-Cavendish

\begin{abstract}
The development of more cold-tolerant short-cycle banana cultivars has made subtropical production possible, but fruiting may be unreliable in colder margins, such as the coastal region of Alabama, as a result of cold winter temperatures and other suboptimal growing conditions. Thus, the objectives of this study were to determine plant growth parameters that predict flowering, and to evaluate vegetative and reproductive growth of Cavendish and non-Cavendish banana cultivars. Pseudostem circumference and the height-to-circumference ratio (HCR) for tall cultivars and HCR for medium cultivars exhibited linear or quadratic relationships when regressed to the number of days from planting to inflorescence emergence (DPE), and hence were the best predictors of inflorescence emergence. The banana cultivars Double, Grand Nain, Cardaba, Ice Cream, and Goldfinger demonstrated cropping potential by producing mature bunches in the cooler environment of the subtropics and currently offer the best possibilities for banana production in Alabama.
\end{abstract}

Intrinsic to many cultures, bananas are an important source of food, fiber, and income, and are vital to the economies of many

Received for publication 12 June 2018. Accepted for publication 4 Sept. 2018.

This project was supported by the Alabama Agricultural Experiment Station and the Hatch program of the National Institute of Food and Agriculture, U.S. Department of Agriculture and the Alabama Fruit, Nut and Vegetable Industries.

We thank Director Malcomb Pegues, Associate Director Jarrod Jones, Horticultural Specialist Bryan Wilkins, and all the support staff of the Gulf Coast Research and Extension Center in Fairhope, $\mathrm{AL}$, for daily maintenance of banana planting and assistance with data collection. We also thank Auburn University graduate students Andrej Svyantek and Roy Langlois for their valuable assistance. We thank Agri-Starts Wholesale Nursery (Apopka, FL) for donating the banana plants for this study.

${ }^{1}$ Corresponding author. E-mail: edc0001@auburn. edu. nations (Ayala-Silva et al., 2008; Cruz da Silva et al., 2010; Ouma, et al., 2010). Global production of bananas has been estimated at over one billion metric tons cumulatively since 2006 (FAOSTAT, 2017). In addition, bananas are the leading import fruit crop in the United States, with an estimated value of \$2 billion in 2013 (FAOSTAT, 2017).

The Cavendish banana is comprised of several genetically related cultivars and is a subgroup of bananas that dominates the global banana market. Classically, bananas are tropical, monocotyledonous, herbaceous in nature, and have a center of origin in southeastern Asia and the western Pacific, and a secondary center of diversity in Africa (De Langhe et al., 2009; Lessard, 1992; Perrier et al., 2011; Robinson, 1996a). Cavendish bananas are imported to the United States primarily from Ecuador, the Philippines, Costa Rica, and Colombia, and are sold at low prices (Koeppel, 2008). This singular focus on Cavendish bananas creates a seldom-exploited niche market potential for non-Cavendish bananas using the diversity of the various subgroups of the genus Musa such as Mysore (AAB), Pome (AAB), Silk (AAB), Plantain (AAB), and Bluggoe (ABB). Bananas of these subgroups command a greater price; have pulp of varying consistencies, thicknesses, and colors; and have unusual aroma and flavor profiles, some of which are reminiscent of apple or citrus (Perrier et al., 2011; Smith et al., 1998). The tendency to bruise during transport has not been characterized for most of these bananas and is a factor that has kept production and consumption local and largely unknown to the western palate.

Cultivation of bananas with greater adaptability to cooler climates could lead to the development of banana niche markets in nontraditional areas such, as in the subtrop$\mathrm{ical} /$ coastal regions of the United States, and would provide needed crop diversity to help increase sustainability to farming operations. Although Hawaii is the only subtropical state in the United States that produces Cavendish bananas commercially, non-Cavendish banana fruit were cultivated successfully in the southeastern United States, including Georgia, Florida, and Texas (Fonsah et al., 2004; Krewer et al., 2008; Ploetz et al., 1999, 2000). The banana market in Florida has generated up to $\$ 2.5$ million annually (Fonsah et al., 2007; Ploetz et al., 2000). Alabama has a subtropical climate, with the Gulf Coast area having the least temperature fluctuation in the winter months. Erratic temperatures and rainfall occur commonly in the subtropics, and winter temperatures in coastal Alabama can cause freeze damage to aboveground plant parts and can decrease low enough to damage rhizomes. The southeastern United States, similar to other subtropical climates around the world, experiences warm temperatures and high relative humidity for much of the year. Relative humidity moderates temperature and determines demand for water during the months when the most active growth occurs. The determination of this demand shifts to internal plant factors during winter months (Eckstein and Robinson, 1996). These conditions will have an impact on plant growth and harvest.

In the subtropical region of South Florida

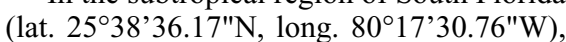
Ayala-Silva et al. (2008) grew five cooking banana cultivars - 'Blue Torres Strait Island' (ABB), 'Bom' (ABB), 'Cacambou' (ABB), 'Gipungusi' (ABB), and 'Pelipita' (ABB)in calcareous soils, for which banana plants are poorly adapted. 'Pelipita' (ABB) produced the tallest pseudostems at fruiting $(361 \mathrm{~cm})$, followed by 'Gipungusi' (352 $\mathrm{cm})$ and by 'Bom' $(264 \mathrm{~cm})$. Bunch weight was the greatest in 'Bom' $(6.8 \mathrm{~kg})$ and 'Pelipita' $(6.5 \mathrm{~kg})$. Number of hands per bunch was the greatest in 'Bom' and 'Pelipita' at 8 and 6 hands/bunch, respectively. Cycling time was the shortest in 'Blue Torres Strait Island' (370 d), 'Cacambou' (368 d), and 'Gipungusi' (343 d). Ploetz et al. (2000) also conducted an evaluation in South Florida 
(lat. $25^{\circ} 30^{\prime} 24.49^{\prime \prime} \mathrm{N}$, long. $80^{\circ} 29^{\prime} 56.77^{\prime \prime W}$ ) of dessert-type bananas 'Goldfinger' (AAAB), 'Pisang Ceylon' (AAB), 'Saba' $(\mathrm{ABB})$, 'Sweetheart' (AABB), 'Kandarian' (ABB), 'Popoulu' (AAB), and 'Veinte Cohol' (AA), with mean bunch weights of 8.9, 7.0, 10.0, 8.9, 14.0, 13.0, and $2.6 \mathrm{~kg}$, respectively. In addition, cycling time for these cultivars were $500,616,506,453$, 826,427 , and $548 \mathrm{~d}$, respectively. In the cooler subtropical region of coastal Georgia (lat. $31^{\circ} 59^{\prime} 54.71^{\prime \prime} \mathrm{N}$, long. $81^{\circ} 16^{\prime} 53^{\prime \prime} \mathrm{W}$ ), Fonsah et al. (2004) evaluated 'Saba', 'Ice Cream', 'Pisang Ceylon', 'Goldfinger', 'Sweetheart', 'Cardaba' (ABB), 'Rajapuri' (AAB), and 'Grand Naine' (AAA). Of these cultivars, 'Cardaba' flowered 25 weeks after planting, but lacked sufficient time for bunch development before frost. Additional cultivars that flowered in the second year were 'Sweetheart', 'Goldfinger', 'Rajapuri', 'Saba', and 'Pisang Ceylon', which were still developing bunches at the time of publication (Fonsah et al., 2005). In a related study, Krewer et al. (2008) reported that 'Rajapuri' and 'Sweetheart' produced mature bunches before frost in coastal Georgia.

\section{Unpredictability of Flower Emergence}

In addition to environmental production challenges, cooler environments also interfere with prediction of flowering and fruiting stages (Robinson and Human, 1988). The onset of reproductive growth (i.e., flowering) has been studied throughout the years (Fahn, 1953; Ram et al., 1962). Unlike many temperate crops, bananas exhibit flowering and fruiting stages that seem to be independent of temperature and light (Robinson and Human, 1988). As a result, physiologic determinants, which signal transition from vegetative to reproductive stages, have been elusive, although increased foliar concentrations of gibberellic acid may be associated with this transition (Robinson and Galán-Saúco, 2010c). In the tropics, Vargas et al. (2009) reported that flowering occurred after a cumulative leaf number (CLN) of 37 to $46 \mathrm{had}$ been reached. Successful prediction of bunch mass and harvest timing in tropical production climates can be performed with simple linear regression models (Guimarães et al., 2013). A simulation model based on a cohort population concept that could predict harvest date accurately as well as the number of harvested bunches of 'Grand Naine' in the French West Indies was developed to address the unsynchronized behavior of individual plants (Tixier et al., 2004). There is an absence of visual cues for flower initiation, other than the emergence of shorter banana leaves, indicating the onset of "shooting," or the emergence of the inflorescence. A means to predict the formation of the inflorescence would help with market and harvest planning.

Abiotic factors such as temperature and solar radiation, and cultural practices such as plant spacing, irrigation, and fertilization will affect leaf emergence rate and number of leaves present (NLP), and these may influ- ence the ability to predict emergence of the inflorescence using CLN. These variables affect photosynthetic capacity, ultimately affecting time of shooting (appearance of the inflorescence at the top of the pseudostem), flower emergence (opening the first floral bract exposing the first flowers), and time of harvest (Turner et al., 2008). Bananas have wide adaptability to abiotic stresses, but demonstrate slow vegetative growth, delayed fruit production, and reduced fruit quality in response to suboptimal growing conditions (Fonsah et al., 2004; Robinson, 1996b; Surendar et al., 2013; Zhang et al., 2012). In addition, flowering at warm temperatures $\left(>22^{\circ} \mathrm{C}\right)$ produced bunches with low fruit weight (Stover and Simmonds, 1987).

Phenologic responses of bananas to a given geographic area are important because they reveal the most environmentally adaptable and economically important cultivars for a region, but are difficult to study in the subtropics as a result of the wide variations in temperature (Robinson, 1996b). These phenomena are an integration of many processes operating over time and are measures of plant vigor and hence hastening toward flowering and maturity (Turner, 1995; Vuylsteke and Ortiz, 1996). Therefore, they can offer insight concerning productive cultivars for a region as well as a potential means to predict flower emergence. The objectives of this study were to evaluate vegetative and reproductive growth of selected Cavendish and nonCavendish banana cultivars under subtropical conditions and to determine phenotypic traits that may predict flowering.

\section{Materials and Methods}

Agri-Starts Inc. (Apopka, FL) donated 13 tissue culture-derived Cavendish and nonCavendish banana cultivars for this experiment (Table 1). When received, bananas had three to eight juvenile leaves. These plants were potted in 20-cm-diameter containers with a $73.7-\mathrm{cm}^{3}$ volume on 12 Apr. 2013 using planting media (Promix; Premier Tech Horticulture, Quakertown, PA). Each container received a top dress of $15 \mathrm{~g}$ Osmocote ${ }^{\circledR}$ 14N-2.6P-9.9K (Scotts Miracle-Gro, Marysville, $\mathrm{OH}$ ) on 12 Apr. 2013 and an additional $100 \mathrm{~mL} 20 \mathrm{~N}-1.7 \mathrm{P}-14.1 \mathrm{~K}$ at a concentration of $250 \mathrm{mg} \cdot \mathrm{L}^{-1}$ weekly beginning $22 \mathrm{Apr}$. 2013.

Field preparation. Planting bed rows were prepared previously at the Gulf Coast Research and Extension Center in Fairhope, AL (lat. $30^{\circ} 31^{\prime} 35.018^{\prime \prime} \mathrm{N}$, long. 8753'44.473"W) using a tiller over existing centipede turf (Eremochloa ophiuroides) on a Malbis sandy loam soil. Beds were $15 \mathrm{~m}$ long, $0.9 \mathrm{~m}$ wide, and $0.3 \mathrm{~m}$ high, and were set on 3-m centers. Turf between rows was maintained. Soil $\mathrm{pH}$ was 5.6; therefore, lime was applied to the beds on $10 \mathrm{Jan} .2013$ at a rate of $0.2 \mathrm{~kg} \cdot \mathrm{m}^{-2}$ and incorporated to raise soil $\mathrm{pH}$.

Planting and cultural practices. Bananas were planted in the field on 3 June 2013 when pseudostem lengths reached a minimum of $60 \mathrm{~cm}$. Bananas were spaced $2.4 \mathrm{~m}$ within a row and planted in staggered formation in relation to bananas in an adjacent row. Spacing between rows was $3 \mathrm{~m}$. To minimize shading of shorter banana plants, cultivars were separated by height classes according to Fonsah et al. (2004) and previous experience (E.G. Fonsah, unpublished data), where dwarf plants were 1.5 to $2.5 \mathrm{~m}$ in height, medium plants were 2.5 to $4.2 \mathrm{~m}$ in height, and tall plants were 3.6 to $7.6 \mathrm{~m}$ in height.

Irrigation was supplied through drip line (Irrigation Mart, Rushton, LA) that supplied water at a rate of $6.3 \mathrm{~L} \cdot \mathrm{h}^{-1} \cdot \mathrm{m}^{-1}$ drip tape, providing irrigation at a rate of $64 \mathrm{~mm} /$ week. This was accomplished by an irrigation schedule of $40 \mathrm{~h}$ each week. Glufosinate ammonium broad-spectrum herbicide was applied as needed to manage weeds. Turf maintained between rows was mowed every 2 weeks. Bananas were fertilized according the recommendations of the Soil, Plant, and Water Analysis Laboratory of the University of Georgia. In 2013, fertilizers $10 \mathrm{~N}-4.3 \mathrm{~N}-$ $8.3 \mathrm{~K}$ and $0 \mathrm{~N}-20.1 \mathrm{P}-0 \mathrm{~K}$ were hand-applied

Table 1. Days from planting to flower emergence of dwarf, medium, and tall banana cultivars at the Gulf Coast Research and Extension Center, Fairhope, AL. Unless otherwise stated, values represent means of three to five replications.

\begin{tabular}{llccr}
\hline Cultivar & Height class & Genetic group & 2014 & 2015 \\
\hline Dwarf Cavendish & Dwarf & AAA & $526^{\mathrm{x}}$ & 843 \\
Double & Dwarf & AAA & $486^{\mathrm{x}}$ & 811 \\
Grand Nain & Dwarf & AAA & 485 & 825 \\
Dwarf Green & Dwarf & AAA & $-{ }^{\mathrm{w}}$ & - \\
Dwarf Red & Dwarf & AAA & 520 & - \\
Goldfinger & Medium & AAAB & 490 & 821 \\
Cardaba & Medium & ABB & - & 800 \\
Ice Cream & Medium & AAB & - & 869 \\
Rajapuri & Medium & AAB & - & 869 \\
Veinte Cohol & Medium & AA & - & - \\
Pisang Ceylon & Tall & AAB & - & 876 \\
Sweetheart & Tall & AABB & - & 829 \\
Saba & Tall & ABB & & - \\
\hline
\end{tabular}

${ }^{\mathrm{z}}$ Dwarf, 150-250 cm; medium, 250-420 cm; tall, 360-760 cm.

${ }^{\mathrm{y}} \mathrm{A}$ and $\mathrm{B}$ indicate genetic contributions of Musa acuminata and M. balbisianna. Number of letters indicates ploidy level.

${ }^{\mathrm{x}}$ Means derived from two replications.

${ }^{\mathrm{w}}$ No plants flowered. 
monthly in circular fashion $60 \mathrm{~cm}$ from the base of plants at rates of $180 \mathrm{~kg} \cdot \mathrm{ha}^{-1} \mathrm{~N}$ and $33.5 \mathrm{~kg} \cdot \mathrm{ha}^{-1} \mathrm{P}$, respectively. In 2014 and $2015,20 \mathrm{~N}-0 \mathrm{P}-0 \mathrm{~K}$ and $0 \mathrm{~N}-0 \mathrm{P}-41.5 \mathrm{~K}$ were injected weekly through the irrigation system to supply $\mathrm{N}$ and $\mathrm{K}$ at rates of $180 \mathrm{~kg} \cdot \mathrm{ha}^{-1}$ and $40 \mathrm{~kg} \cdot \mathrm{ha}^{-1}$, respectively.

Lateral meristems (suckers) were maintained by monthly cutting and hand removal. Suckers were cut at soil level and were covered with soil to prevent microbial invasion according to Fonsah and Chidebelu (1995) and Robinson and Gálan-Saúco (2010b). One sucker was allowed to remain to serve as a successor plant (ratoon) for the following season. Cultivars were planted using an experimental design that consisted of six single-plant replications arranged in a completely randomized design with cultivar and days after planting (DAP) until day of data collection as main effects.

Data collection. Phenotypic measurements consisted of 1) pseudostem height as measured from the ground to the bifurcation formed by the petiole bases of the top two leaves; 2) pseudostem circumference taken at $30 \mathrm{~cm}$ above the ground; 3) HCR; 4) leaf area index (LAI), which is the total leaf area divided by unit ground area; 5) NLP at time of data collection determined at each time of data collection; 6) CLN, which is the total number of mature leaves to date of each plant; 7) total leaf area (TLA); and 8) width and length of leaves in the third position on the pseudostem from the top of each plant. Additional data collected include DAP and DPE (exposure of first flower set of the inflorescence). Phenotypic measurements were recorded on a semimonthly basis in 2014 (342, 371, 399, 442, 467, and 490 DAP) and $2015(705,743,785,812$, and 869 DAP), and when all female flowers of the inflorescence had been exposed and revealed the visually prominent ovaries or maturing banana fruit. Bananas were harvested according to Daniells et al. (1987), when the two middle fingers of the outer whirl of the third hand reached a minimum diameter of $3 \mathrm{~cm}$. Mature bunches were harvested on 18 Dec. 2015. Bunch weight was recorded and consisted of weight of all fruit including the rachis. Other bunch data were total number of fingers (individual banana fruit) per bunch, total number of fingers per hand (a group of fingers on a banana bunch that consists of a variable number of fingers), total number of hands per bunch, and total number of fingers per bunch.

TLA was calculated using the following equation (Nyombi et al., 2009):

$$
\mathrm{TLA}=[(\mathrm{LAF} \times \mathrm{L} \times \mathrm{W}) \times \mathrm{NLP}],
$$

where $\mathrm{LAF}$ is the leaf area factor, $\mathrm{L}$ is the leaf length, and $\mathrm{W}$ is leaf width. A value of 0.8 was selected (Potdar and Pawar, 1991) for LAF. Leaf area was calculated using length and width data of the leaf in the third position from the top of the pseudostem. This value was then multiplied by the NLP at the time of leaf measurement.
LAI was determined using the following equation (Nyombi et al., 2009):

$$
\mathrm{LAI}=\frac{\mathrm{TLA}}{\text { Plant area spacing }} .
$$

Statistics. An analysis of variance was performed on all responses using PROC GLIMMIX in SAS version 9.4 (SAS Institute, Cary, NC). Each height class was analyzed separately. The experimental design was completely randomized, with repeated measures over DAP. Akaike information criterion fit statistics were used to select the best covariance structures for the repeated measures. The treatment design was a two-way factorial of cultivar and DAP. Linear and quadratic trends over DAP were tested using qualitative-quantitative regression models. Least-squares means comparisons among cultivars were determined using the simulated method. Model regressions were used to test linear and quadratic trends predicting pseudostem circumference and HCR from DPE over all cultivars and years with appropriate lack-of-fit terms. Year was entered as a random variable in these models. All measures of significance were set at $\alpha=0.05$.

\section{Results}

Mother plants or plant crop set in the field on 3 June 2013 succumbed to the uncharacteristically low temperatures of late Dec. 2013 and early Jan. 2014. In most cases, rhizomes survived and suckers or the ratoon crop began to emerge and produce mature leaves by 18 Mar. 2014. The ratoon crop developed more vigorously than the plant crop, benefitting from the reserves in the rhizome accumulated during the previous season. Flower emergence occurred in some cultivars in Oct. 2014 (Table 1), but there was not sufficient time for harvest of mature fruit before the onset of winter.

Flower emergence was determined from the date of planting in 2013. In 2014, there was a one-day difference in DPE between 'Grand Nain' (485) and 'Double' (486), which occurred $40 \mathrm{~d}$ earlier than 'Dwarf Cavendish' (Table 1). Among mediumheight bananas, DPE occurred $30 \mathrm{~d}$ earlier in 'Cardaba' (490) than 'Goldfinger' (520), whereas 'Pisang Ceylon' was the only cultivar to flower (523 DPE) among tall cultivars. Additional cultivars that flowered in 2015 were two medium cultivars - 'Rajapuri' (868) and 'Ice Cream' (869) — and 'Sweetheart' (829 DAP) among the tall cultivars.

Flower emergence did not occur in several cultivars in each height category in either 2014 or 2015: 'Dwarf Green' and 'Dwarf Red' (dwarf cultivars), 'Veinte Cohol' (medium-height cultivars), and 'Saba' (tall cultivars).

Few phenotypic traits revealed a significant relationship to DPE among types and cultivars of bananas following regression analysis, and these relationships were relative to height classification (Table 2). Lack-of-fit value for each equation was not significant, indicating that a linear model explains all variation. HCR was inversely proportional to DPE in medium-height bananas but exhibited a significant positive relationship to DPE in tall cultivars. In addition, there was a significant relationship between pseudostem circumference and DPE in tall cultivars.

The HCR of 'Goldfinger' banana (Table 3) was significantly less than that of all other medium-height banana cultivars at 342 and 371 DAP, but similar to those of 'Ice Cream' (3.0) and 'Cardaba' (3.4) at 442 DAP. At 467 DAP, HCR of 'Goldfinger' was similar to all medium-height banana cultivars with the exception of 'Cardaba'. By the latter portion of the season (490 DAP), HCR was similar among all medium-height banana cultivars. In early-season growth, HCR was not different among tall cultivars in 2014. In midto late-season growth (399-490 DAP), the HCR of 'Pisang Ceylon' banana plants were statistically greater than those of 'Saba' and 'Sweetheart'. In contrast, the HCR of 'Sweetheart' was less than both 'Saba' and 'Pisang Ceylon' at 467 and 490 DAP, respectively.

The HCR of medium and tall cultivars differed only twice in 2015 (Table 4). Low HCR values are desirable, and 'Goldfinger' banana plants were among the lowest numerically and differed from other cultivars at 785 DAP and 812 DAP. There was an interaction between cultivar and DAP accountable for HCR in medium cultivars. Only the cultivar and DAP main effects were significant for the tall cultivars. HCR across tall banana cultivars showed a quadratic trend with a range of 3.7 to 4.0. Similar to the previous season, HCR of 'Sweetheart' was less than that of 'Pisang Ceylon' and 'Saba'.

Final phenotypic trait comparisons made at the time of flowering or during bunch development showed no differences in any

Table 2. Regression equations predicting the number of days from planting to flower emergence (DPE) from plant circumference (CM) and height-to-circumference ratio (HCR) for medium and tall banana cultivars at the Gulf Coast Research and Extension Center, Fairhope, AL, in 2014 and 2015. Significant linear equations using model regressions over cultivar and years at $P<0.05$.

\begin{tabular}{lcc}
\hline Equation & Linear Pr $>\mathrm{F}$ & Lack-of-fit $\operatorname{Pr}>\mathrm{F}$ \\
\hline Medium $^{\mathrm{z}}$ & 0.0125 & 0.3417 \\
$\mathrm{DPE}=7.06-9 \times \mathrm{HCR}$ & & \\
Tall & 0.0261 & 0.5395 \\
$\mathrm{DPE}=700.1-3.8 \times \mathrm{CM}$ & $<0.0001$ & 0.4607 \\
$\mathrm{DPE}=596.3+22.3 \times \mathrm{HCR}$ &
\end{tabular}

${ }^{\mathrm{z}}$ Medium and tall bananas are 250 to $420 \mathrm{~cm}$ and 360 to $760 \mathrm{~cm}$, respectively. $\operatorname{Pr}=$ probability. 
variables among the dwarf cultivars (Table 5). In medium-height banana plants, 'Ice Cream' had larger pseudostems than the other cultivars based on plant height and circumference. There were no differences in HCR or in LAI among medium banana cultivars, but differences were found in NLP at flowering, which were greatest in 'Ice Cream' and 'Cardaba' compared with 'Goldfinger' or 'Rajapuri'.

The pseudostem height of 'Pisang Ceylon' and 'Sweetheart' was less than the criterion for tall cultivars (Table 5). Height of 'Pisang Ceylon' at flowering was greater than that of 'Sweetheart', whereas 'Sweetheart' bananas had greater plant circumference. Shorter plant height and thicker pseudostem circumference resulted in a lower HCR in 'Sweetheart' compared with 'Pisang Ceylon'.

The bunch weight (yield) of individual plants among dwarf and medium cultivars was low (Table 6). Comparison in yield was made only between 'Double' and 'Grand Nain' as a result of a lack of a sufficient number of plants that produced bunches. Bunch weight of 'Double' was greater than that of 'Grand Nain'. There were no differences in bunch characteristics of total hand number per bunch, total finger number per bunch, and total number of fingers per hand.

Medium-height 'Goldfinger' and 'Ice Cream' produced more hands per bunch and fingers per bunch than 'Cardaba' and 'Raja- puri'. 'Cardaba' had the least number of fingers per hand compared with other cultivars. 'Rajapuri' lacked mature bunches and was not used to compare total yields; yields of the other three cultivars were not significantly different (Table 6).

\section{Discussion}

Despite rare, abnormally low-temperature weather events during this study, the climate of the Alabama Gulf Coast is generally mild and conducive for optimal growth of banana plants. Historically, temperatures of the region (Fig. 1A) fall mostly within the cardinal temperature range for banana production (Robinson and Galán-Saúco, 2010a). Turner

Table 3. Height-to-circumference ratio of medium and tall banana cultivars at specific days after planting (DAP) that were grown at the Gulf Coast Research and Extension Center, Fairhope, AL, in 2014.

\begin{tabular}{|c|c|c|c|c|c|c|c|}
\hline Cultivar $^{2}$ & 342 DAP & 371 DAP & 399 DAP & 442 DAP & 467 DAP & 490 DAP & Sign. \\
\hline \multicolumn{8}{|l|}{$\overline{\text { Medium }^{y}}$} \\
\hline Cardaba & $3.3 \mathrm{a}$ & $3.2 \mathrm{a}$ & $3.6 \mathrm{a}$ & $3.4 \mathrm{ab}$ & $4.1 \mathrm{a}$ & $4.0 \mathrm{a}$ & $\mathrm{L}^{* * *}$ \\
\hline Rajapuri & $3.3 \mathrm{a}$ & $3.3 \mathrm{a}$ & $3.6 \mathrm{a}$ & $3.6 \mathrm{a}$ & $3.6 \mathrm{ab}$ & $3.9 \mathrm{a}$ & $\mathrm{L}^{* * *}$ \\
\hline \multicolumn{8}{|l|}{ Tall } \\
\hline Pisang Ceylon & $3.0 \mathrm{a}$ & $3.2 \mathrm{a}$ & $3.9 \mathrm{a}$ & $3.8 \mathrm{a}$ & $4.1 \mathrm{a}$ & $4.3 \mathrm{a}$ & $\mathrm{L}^{* * *}$ \\
\hline Saba & $3.3 \mathrm{a}$ & $3.1 \mathrm{a}$ & $3.2 \mathrm{~b}$ & $2.8 \mathrm{~b}$ & $3.4 \mathrm{~b}$ & $3.5 \mathrm{~b}$ & $\mathrm{~L}^{* *}$ \\
\hline
\end{tabular}

${ }^{\mathrm{z}}$ There was a significant cultivar-by-DAP interaction at $P<0.05$.

${ }^{\mathrm{y}}$ Medium and tall bananas are 250 to $420 \mathrm{~cm}$ and 360 to $760 \mathrm{~cm}$, respectively.

${ }^{\mathrm{x}}$ Least-square means comparisons among cultivars (lowercase in columns) using the simulated method at $P<0.05$. Mean values within columns and within size with the same letter are not significantly different.

${ }^{*},{ }^{*},{ }^{* * *}$ Significant linear $(\mathrm{L})$ and quadratic $(\mathrm{Q})$ response of height-to-circumference ratio for each cultivar at $P<0.05,0.01$, or 0.001 , respectively.

Table 4. Effects of cultivar and number of days after planting (DAP) on height-to-circumference ratio of medium and tall banana cultivars at the Gulf Coast Research and Extension Center, Fairhope, AL, in 2015.

\begin{tabular}{|c|c|c|c|c|c|c|}
\hline Cultivar & 705 DAP & 743 DAP & 785 DAP & 812 DAP & 869 DAP & Sign \\
\hline Goldfinger & $4.2 \mathrm{a}$ & $3.7 \mathrm{a}$ & $3.6 \mathrm{c}$ & $4.2 \mathrm{c}$ & $4.1 \mathrm{a}$ & NS \\
\hline Ice Cream & $3.9 \mathrm{a}$ & $4.0 \mathrm{a}$ & $4.1 \mathrm{~b}$ & $5.0 \mathrm{~b}$ & $4.0 \mathrm{a}$ & NS \\
\hline Tall cultivars (all) ${ }^{\mathrm{x}}$ & 3.8 & 3.7 & 3.7 & 4.3 & 4.0 & $\mathrm{Q}^{* *}$ \\
\hline \multicolumn{7}{|c|}{ Tall cultivars ${ }^{\mathrm{w}}$} \\
\hline \multicolumn{2}{|c|}{ Pisang Ceylon } & \multicolumn{3}{|c|}{ Saba } & \multicolumn{2}{|c|}{ Sweetheart } \\
\hline
\end{tabular}

${ }^{\mathrm{z}}$ There was a significant cultivar-by-DAP interaction at $P<0.05$ among medium height cultivars. Mean values within a column with the same letter are not significantly different.

${ }^{\mathrm{y}}$ Medium and tall bananas were 250 to $420 \mathrm{~cm}$ and 360 to $760 \mathrm{~cm}$, respectively.

${ }^{\mathrm{x}}$ Mean HCR values across all tall cultivars at each DAP. Only the cultivar main effect was significant

${ }^{\mathrm{w}}$ Least square means comparisons among cultivars using the simulated method $P<0.05$. Mean values with same letter are not significantly different $(P<0.05)$. Ns, *, **Nonsignificant and significant quadratic (Q) trend using qualitative/quantitative regression models at $P<0.05$ or 0.01 , respectively.

Table 5. Phenotypic comparisons of dwarf, medium-height, and tall banana cultivars (Musa sp.) at flower emergence at the Gulf Coast Research and Extension Center, Fairhope, AL, in 2015.

\begin{tabular}{|c|c|c|c|c|c|c|}
\hline Cultivar $^{2}$ & Plant ht $(\mathrm{cm})$ & Plant circumference $(\mathrm{cm})$ & Ht:circumference ratio & No. of leaves present & Leaf area index & Cumulative leaf no \\
\hline \multicolumn{7}{|l|}{$\overline{\text { Dwarf }^{y}}$} \\
\hline Grand Naine & $156.6 \mathrm{a}$ & $54.55 \mathrm{a}$ & $2.98 \mathrm{a}$ & $9.75 \mathrm{a}$ & $0.86 \mathrm{a}$ & $24.4 \mathrm{a}$ \\
\hline \multicolumn{7}{|l|}{ Medium } \\
\hline Cardaba & $266.4 \mathrm{~b}$ & $58.62 \mathrm{~b}$ & $4.29 \mathrm{a}$ & $12.8 \mathrm{a}$ & $1.26 \mathrm{a}$ & $23.8 \mathrm{~b}$ \\
\hline Goldfinger & $229.34 \mathrm{c}$ & $53.30 \mathrm{bc}$ & $4.09 \mathrm{a}$ & $9.16 \mathrm{~b}$ & $1.10 \mathrm{a}$ & $25.1 \mathrm{~b}$ \\
\hline Rajapuri & $195.07 \mathrm{~d}$ & $47.94 \mathrm{c}$ & $4.32 \mathrm{a}$ & $8.83 \mathrm{~b}$ & $2.51 \mathrm{a}$ & $21.8 \mathrm{~b}$ \\
\hline \multicolumn{7}{|l|}{ Tall } \\
\hline Pisang Ceylon & $247.90 \mathrm{a}$ & $52.11 \mathrm{~b}$ & $4.70 \mathrm{a}$ & $7.0 \mathrm{a}$ & - & $27.5 \mathrm{a}$ \\
\hline
\end{tabular}

${ }^{\mathrm{z}}$ Least-square means comparisons among cultivars using the simulated method $P<0.05$.

${ }^{\mathrm{y}}$ Dwarf, medium-height, and tall bananas are 150 to $250 \mathrm{~cm}, 250$ to $420 \mathrm{~cm}$, and 360 to $760 \mathrm{~cm}$ in height, respectively.

${ }^{\mathrm{x}}$ Mean values within columns and within size with same letters are not significantly different $(P<0.05)$.

${ }^{\mathrm{w}}$ Data were not collected. 
Table 6. Phenotypic comparisons of dwarf, medium-height, and tall banana cultivars (Musa sp.) at the Gulf Coast Research and Extension Center, Fairhope, AL, in 2015.

\begin{tabular}{lcccc}
\hline Cultivar $^{z}$ & Yield/bunch $(\mathrm{kg})$ & Total hand no./bunch & Total finger no./bunch & Fingers/hand \\
\hline Dwarf & & & & \\
Double & $11.86 \mathrm{a}^{\mathrm{x}}$ & $8.76 \mathrm{a}$ & $129 \mathrm{a}$ & $17.3 \mathrm{a}$ \\
$\quad$ Grand Naine & $5.76 \mathrm{~b}$ & $8.3 \mathrm{a}$ & $136 \mathrm{a}$ & $17.0 \mathrm{a}$ \\
Medium & & & & \\
Goldfinger & $6.6 \mathrm{a}$ & $9.5 \mathrm{a}$ & $138.0 \mathrm{a}$ & $17.6 \mathrm{a}$ \\
Ice Cream & $7.22 \mathrm{a}$ & $8.2 \mathrm{a}$ & $136.0 \mathrm{a}$ & $16.2 \mathrm{a}$ \\
Cardaba & $6.76 \mathrm{a}$ & $6.3 \mathrm{~b}$ & $74.0 \mathrm{~b}$ & $11.7 \mathrm{~b}$ \\
Rajapuri & $-{ }^{\mathrm{w}}$ & $6.0 \mathrm{~b}$ & $88.4 \mathrm{~b}$ & $17.6 \mathrm{a}$ \\
\hline
\end{tabular}

${ }^{\mathrm{z}}$ Least-square means comparisons among cultivars using the simulated method $P<0.05$.

${ }^{\mathrm{y}}$ Dwarf and medium-height bananas are 150 to $250 \mathrm{~cm}$ (dwarf), 250 to $420 \mathrm{~cm}$, and 360 to $760 \mathrm{~cm}$ in height.

${ }^{\mathrm{x}}$ Mean values within columns and within size with same letters are not significantly different $(P>0.05)$.

${ }^{\mathrm{w}}$ Bunches were immature. Therefore, bunch weight was not measured.

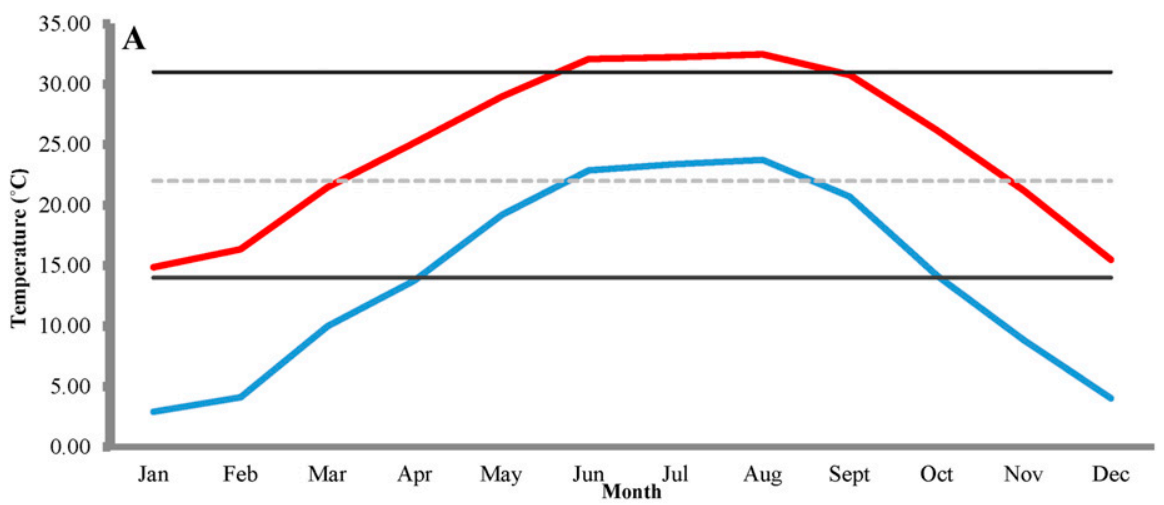

B

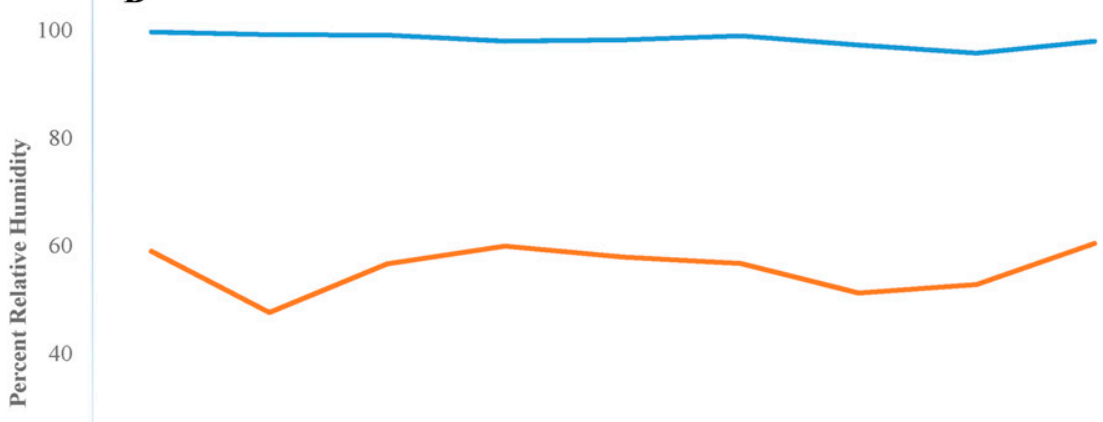

20

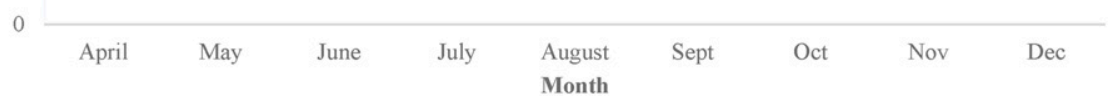

Fig. 1 (A) Cardinal temperature range for 'Cavendish' and non- 'Cavendish' banana (Musa sp.) compared with historical mean monthly maximum and minimum temperatures in Fairhope, AL. Cardinal temperatures are between the upper and lower bold lines; optimal temperatures are between the upper bold and dotted lines. Temperature data were retrieved from the Alabama mesonet and represent 8 years of data. (B) Average monthly maximum and minimum percent relative humidity in Fairhope, AL. Weather data gathered from 2013 to 2015 during the most actively growing periods of bananas. Percent relative humidity data were retrieved from the Alabama mesonet. The top and bottom lines indicate maximum and minimum percent relative humidity, respectively.

and Lahav (1983) reported that high and low temperatures of $33{ }^{\circ} \mathrm{C}$ and $24{ }^{\circ} \mathrm{C}$ produced the largest plants. Low temperatures and variations between day- and nighttime temperatures are major impediments to flower initiation and bunch development, and is the primary concern for banana production in subtropical regions (Robinson, 1996b; Smith et al., 1998). Relative humidity was another important factor. Turner and Lahav (1983) stated that leaf water content was more related to relative humidity, expressed as vapor pressure deficit (VPD), than to temperature. A greater VPD can interfere with growth rate and rate of photosynthesis, and, ultimately, will influence bunch formation (Eckstein and Robinson, 1996c; Galán-Saúco et al., 1998; Turner and Lahav, 1983). Average monthly maximum relative humidity in the subtropical region of the Gulf Coast was near capacity, allowing little concern for water stress (Fig. 1B). Nevertheless, previous studies in subtropical banana cultivation have demonstrated potential for banana production in the subtropics and their marketability in both local and international venues (Denger et al., 1997; Krewer et al., 2008; Langdon et al., 2008; Lessard, 1992; Robinson, 1996b).

Several banana cultivars demonstrated adaptability to the environment of coastal Alabama in that they produced mature bunches within the relatively short crop production period, whereas others did not flower or demonstrated untimely flower emergence. Banana plants that produced mature bunches most reliably in this study were the dwarf cultivars 'Double' and 'Grand Nain', and the medium cultivars 'Ice Cream', 'Cardaba', and 'Goldfinger'. Compared with cultivars produced in other regions, bunch weight was relatively low as this is a factor controlled partially by environment (Baiyeri et al., 2004). In the current study, bunch weight ranged between 5.8 and $11.9 \mathrm{~kg}$, which is less than the reported mean bunch weight of $20.1 \mathrm{~kg}$ for plants across cultivars, subgroups, and ploidy levels (Baiyeri et al., 2004; Eckstein et al., 1998; Langdon et al., 2008; Smith et al., 1998; Vargas et al., 2009).

The best phenotypic traits for predictors of flower emergence and consistent timely flower emergence and bunch development were HCR and DPE. CLN has been used traditionally as a predictor of flower emergence, but there was no linear relationship between CLN and DPE in our study (data not shown). Conversely, the phenotypic descriptors of pseudostem circumference and HCR were correlated to DPE, and hence could serve as predictors of flowering in medium-height and tall banana cultivars. Curiously, HCR had an inversely proportional rather than a positive relationship to DPE in this study. This could be attributed to differences in vertical growth in relation to plant circumference. The HCR of tall cultivars tended to increase more dramatically throughout the season, and therefore demonstrated a positive relationship to DPE.

In shorter banana cultivars, HCR tended to remain unchanged or even to decrease throughout the season and demonstrated an inversely proportional relationship to DPE. Differences in the HCR between domestic and forest-grown bananas in the genus Ensete was noted by Hildebrand (2001). Domestic Ensete continued vigorous vertical growth whereas basal girth reached a maximum more quickly. Conversely, vertical growth was parallel to basal growth in forest-grown Ensete. The tendency of HCR to fluctuate or remain unchanged for several weeks before DPE did not offer a practical tool in the prediction of DPE in Ensete bananas. For this reason, the current study suggests the use of pseudostem circumference measurements as an indicator of DPE in tall cultivars appears to be more practical than HCR.

'Dwarf Green', 'Dwarf Red', and 'Saba' did not exhibit adaptability to the Gulf Coast environment in that they did not flower. On the other hand, despite the low survivability of 'Veinte Cohol' banana plants in our study, floral initiation occurred during the first season (2013), as was evidenced by the presence of a true stalk in each cross-section of winter-killed 
pseudostems. 'Veinte Cohol' is a diploid with $100 \%$ of its genetic background coming from $M$. acuminata and is known to have a short production cycle. Bananas having short production cycles yield a mature crop in a single season (Jarret et al., 1993), so cultivars with this trait may be the best option for planting in the cooler subtropics and they could be treated as an annual plant. Certain traits found in diploid bananas may limit their use. Ploetz et al. (2000) reported diploid accessions had low productivity compared with those of higher ploidy in general. Plants of 'Veinte Cohol' could be protected by cultural practices, such as mulch or high tunnels to protect the rhizome from cooler temperatures (Cabrera et al., 1998).

\section{Conclusion}

An ideal cultivar suitable to the subtropical environment along coastal Alabama and other subtropical regions should have consistent, yearly production at commercial levels if it is to be considered for inclusion in a new banana niche market. 'Goldfinger', 'Double', 'Grand Nain', 'Cardaba', and 'Ice Cream' are possible choices to date for this region. Alternatively, annual production of a rapidflowering type such as 'Veinte Cohol' offers another aspect for banana production. Prediction of DAP to DPE were best estimated using regressions of plant circumference and HCR.

\section{Literature Cited}

Ayala-Silva, T., R.J. Schnell, A.W. Meerow, J.S. Brown, and G. Gordon. 2008. A study on the morphological and physicochemical characteristics of five cooking bananas. J. Agron. 8:33-38.

Baiyeri, K.P., A. Tenkouano, B.N. Mbah, and J.S.C. Mbagwu. 2004. Phenological and yield evaluation of Musa genotypes under alley and sole cropping systems in southeastern Nigeria. Trop. Subtrop. Agroecosystems 2004:137-144.

Cabrera, J.C., V.G. Saúco, P.M. Delgado, and M.C. Rodriguez. 1998. Single-cycle cultivation of in vitro-propagated 'Grande Naine' banana under subtropical conditions. Acta Hort. 490:175-179.

Cruz da Silva, A.V., E.N. Muniz, M. Mourao, and O.R. Duarte. 2010. Growth and development of banana genotypes in Roraima, Brazil. Proc. of the 3rd Intl. Symp. on Trop. and Subtropical Fruit. Acta Hort 864:87-92.

Daniells, J.W., P.J. O'Farrell, J.C. Mulder, and S.J. Campbell. 1987. Effect of plant spacing on yield and plant characteristics of banana in North Queensland. Austral. J. Expt. Agr. 27:727-731.

De Langhe, E., L. Vrydaghs, P. de Maret, X. Perrier, and T. Denham. 2009. Why bananas matter: An introduction to the history of banana domestication. Ethnobot. Res. Appl. 7:165-177.

Denger, R.L., S.D. Moss, and M.D. Mulkey. 1997. Economic impact of agriculture and agribusiness in Dale County, Florida. FAMRC Industry Report. IFAS, Gainesville, FL.

Eckstein, K., C. Fraser, J. Husselmann, and N. Temple Murray. 1998. The evaluation of promising new banana cultivars. Acta Hort. 490:57-68.

Eckstein, K. and J.C. Robinson. 1996. Physiological responses of banana (Musa AAA; Cavendish sub-group) in the subtropics: VI. Seasonal responses of leaf gas exchange to short-term water stress. J. Hort. Sci. 71:679-692.

Fahn, A. 1953. The origin of the banana inflorescence. Kew Bull. 3:299-306.
FAOSTAT. 2017. Glossary. 30 Sept. 2017.<http:// faostat.fao.org/site/en/\#home>.

Fonsah, E.G. and A.S.N. Chidebelu. 1995. Economics of banana production and marketing in the tropics: A case study of Cameroon. Minerva Press, London, UK.

Fonsah, E.G., G. Krewer, and M. Rieger. 2004. Banana cultivar trials for fruit production, ornamental landscape use, and ornamentalnursery production in South Georgia. J. Food Distrib. Res. 35:86-92.

Fonsah, E.G., G. Krewer, and M. Rieger. 2005. Second year banana cultivar trial in South Georgia. J. Food Distrib. Res. 36:48-54.

Fonsah, E.G., G. Krewer, R. Wallace, and B. Mullinix. 2007. Banana trials: A potential niche and ethnic market in Georgia. J. Food Distrib. Res. 38:14-21.

Galán Saúco, V., J. Cabrera, P.M. Hernández Delgado, and M.C. Rodríguez Pastor. 1998. Comparison of protected and open-air cultivation of Grand Naine and Dwarf Cavendish bananas. Acta Hort. 490:247-259.

Guimarães, M.J.M., M.A.C. Filho, C.P. Peixoto, F.D.G. Junior, and V.V.M. de Oliveira. 2013 Estimation of leaf area index of banana orchards using the method LAI-LUX. Water Resources Irr. Mgt. 2:71-76.

Hildebrand, E. 2001. Morphological characterization of domestic vs forest-growing Ensete ventricosum (Welw.) Cheesman, Musaceae, in Sheko district, Bench-Maji Zone, southwest Ethiopia. Biologiske Skrifter 54:287-309.

Jarret, R., D.R. Vuylsteke, N.J. Gawel, and L.J. Dunbar. 1993. Detecting genetic diversity in diploid bananas using PCR and primers from a highly repetitive DNA sequence. Euphytica 68:69-76.

Koeppel, D. 2008. Banana: The fate of the fruit that changed the world. Penguin Group, New York, NY.

Krewer, G., E.G. Fonsah, M. Rieger, R. Wallace, D. Linvill, and B. Mullinix. 2008. Evaluation of commercial banana cultivars in southern Georgia for ornamental and nursery production. HortTechnology 18:529-535.

Langdon, P.W., A.W. Whiley, R.J. Mayer, K.G. Pegg, and M.K. Smith. 2008. The influence of planting density on the production of 'Goldfinger' (Musa spp., AAAB) in the subtropics. Scientia Hort. 115:238-243.

Lessard, W.O. 1992. The complete book of bananas. 1st ed. William O. Lessard. Cornell University, Ithaca, NY.

Nyombi, K., P.J.A. van Asten, P.A. Leffelaar, M. Corbeels, C.K. Kaizzi, and K.E. Giller. 2009. Allometric growth relationships of East African highland bananas (Musa AA-EAHB) cv. Kisansa and Mbwazirume. Ann. Appl. Biol. 155:403-418.

Ouma, E., J. Jagwe, A.O. Gideon, and S. Abele. 2010. Determinants of smallholder farmers' participation in banana markets in Central Africa: The role of transaction costs. Agr. Econ. 41:111-122.

Perrier, X., E. De Langhe, M. Donohue, C. Lentfer, L. Vrydaghs, F. Bakry, F. Carreel, I. Hippolyte, J. Horry, C. Jenny, V. Lebot, A. Risterucci, K. Tomekpe, H. Doutrelepont, T. Ball, J. Manwaring, P. DeMaret, and T. Denham. 2011. Multidisciplinary perspectives on banana (Musa spp.) domestication. Proc. Natl. Acad. Sci. USA 108:11311-11318.

Ploetz, R.C., J.L. Haynes, and A. Vasquez. 1999. Evaluation of bananas for niche markets in subtropical Florida. Infomusa 8:15-18.

Ploetz, R.C., J.L. Haynes, A. Vazquez, and D. Benscher. 2000. Performance of new banana germplasm in South Florida. HortScience $35: 120-124$.
Potdar, M.V. and K.R. Pawar. 1991. Nondestructive leaf area estimation in banana. Scientia Hort. 45:251-254.

Ram, H.Y.M., M. Ram, and F.C. Steward. 1962. Growth and development of the banana plant 3 A. The origin of the inflorescence and the development of the flowers. B. Structure and development of the fruit. Ann. Bot. 26:657-673.

Robinson, J.C. 1996a. Distribution and importance, p. 1-7. In: J. Atherton and A. Rees (eds.). Bananas and plantains. $\mathrm{CAB}$ International, Wallingford, UK.

Robinson, J.C. 1996b. Climatic requirements and problems, p. 48-69. In: J. Atherton and A. Rees (eds.). Bananas and plantains. CAB International, Wallingford, UK.

Robinson, J.C. 1996c. Phenological and physiological responses, p. 70-94. In: J. Atherton and A. Rees (eds.). Bananas and plantains. $\mathrm{CAB}$ International, Wallingford, UK

Robinson, J.C. and V. Galán-Saúco. 2010a. Climatic requirements and problems, p. 67-87. In: S. Hulbert and F. Chippendale (eds.). Bananas and plantains. CAB Intl., Univ. Press, Wallingford, Oxfordshire, UK.

Robinson, J.C. and V. Galán-Saúco. 2010b. Horticultural management, p. 193-216. In: S. Hulbert and F. Chippendale (eds.). Bananas and plantains. CAB Intl., Univ. Press, Wallingford, Oxfordshire UK

Robinson, J.C. and V. Galán-Saúco. 2010c. Morphological characteristics and plant development, p. 51-66. In: S. Hulbert and F. Chippendale (eds.). Bananas and plantains. CAB Intl., Univ. Press, Wallingford, Oxfordshire, UK

Robinson, J.C. and N.B. Human. 1988. Forecasting of banana harvest ('Williams') in the subtropics using seasonal variations in bunch development rate and bunch mass. Scientia Hort. $34: 249-263$

Smith, M.K., S.D. Hamill, P.W. Langdon, and K.G. Pegg. 1998. Selection of new banana varieties for the cool subtropics in Australia. Acta Hort. 490:49-56.

Stover, R.H. and N.W. Simmonds. 1987. Bananas 3rd ed. Longman Group, Essex, England.

Surendar, K.K., D.D. Devi, I. Ravi, P. Jeyakumar, R.S. Kumar, and K. Velayudham. 2013. Studies on the impact of water deficit on plant height, relative water content, total chlorophyll, osmotic potential and yield of banana (Musa spp.) cultivars. J. Hort. 3:52-56.

Tixier, P., E. Malezieux, and M. Dorel. 2004. SIMBA-POP: A cohort population model for long term simulation of banana crop harvest. Ecol. Modell. 180:407-417.

Turner, D.W. 1995. The response of the plant to the environment, p. 206-229. In: S. Gowen (ed.). Bananas and plantains. Chapman and Hall, London, UK.

Turner, D.W., J.A. Fortescue, and D.S. Thomas. 2008. Environmental physiology of the bananas (Musa spp.). Braz. J. Plant Physiol. 19:463-484.

Turner, D.W. and E. Lahav. 1983. The growth of banana plants in relation to temperature. Austral. J. Plant Physiol. 10:43-53.

Vargas, A., M. Araya, M. Guzman, and G. Murillo. 2009. Effect of leaf pruning at flower emergence of banana plants (Musa AAA) on fruit yield and black Sigatoka (Mycosphaerella fijiensis) disease. Intl. J. Pest Mgt. 55:19-25.

Vuylsteke, D.R. and R. Ortiz. 1996. Field performance of conventional vs. in vitro propagules of plantain (Musa spp., AAB group). HortScience 31:862-865.

Zhang, J.Z., Q. Zhang, Y.L. Chen, L.L. Sun, L.Y. Song, and C.L. Peng. 2012. Improved tolerance toward low temperature in banana (Musa AAA Group Cavendish Williams). S. Afr. J. Bot. 78:290-294. 